Journal of the Egyptian Society of Parasitology, Vol.43, No.1, April 2013

J. Egypt. Soc. Parasitol., 43(1), 2013: 23 - 32

\title{
GENETICALLY CONFIRMED FASCIOLA HEPATOGIGANTICA N.SP.
}

\author{
REFAAT M.A. KHALIFA*, HANAA A. EL-HADY, EMAN K. OMRAN \\ AND NOHA S. AHMED \\ Departments of Medical Parasitolgy, Faculties of Medicine, Assiut* and \\ Sohag Universities
}

Correspondence: e-mail, rkhalifa_eg@yahoo.com or moabdallah.1998@hotmail.com

\section{Abstract}

Identification of liver fluke species cannot be achieved by clinical, pathological, coprological or immunological methods. However, the differential diagnosis between $F$. hepatica and $F$. gigantica infection is very important because of their different pathological manifestations. Moreover, in countries where the two species co-exist, morphologically intermediate forms were reported. The present study aimed to identify these forms by the use of molecular characterization of DNA sequence.

Based on morphometric criteria, adults of Fasciola hepatica, F. gigantica and intermediate forms were collected from naturally infected sheep and cattle from various regions of Sohag Governorate. A simple and rapid new method (QIAamp DNA Mini Kit) was used to isolate DNA from the worms and their RELP patterns were obtained after digestion of the PCR products with AvalI restriction enzymes.

The result of a regular PCR experiment for the amplification of the selected $28 \mathrm{~S}$ rDNA fragment with the designed primer set yielded identical 618-bp-long PCR products for the three types of Fasciola where the RFLP profile obtained from $F$. hepatica revealed four fragments of $628,575,165$ and $95 \mathrm{bp}$, and $F$. gigantica generated three fragments corresponding to 628,358 and $300 \mathrm{bp}$ fragments whereas the intermediate forms revealed four fragments of 628, 541, 358 and $300 \mathrm{bp}$, which were similar to those of $F$. gigantica but with a distinctive fragment of 541 .

These results confirmed that three species are present in our locality: $F$. hepatica, $F$. gigantica and an intermediate form which was named $F$. hepatogigantica $n . s p$. on basis of having few morphometric characters from $F$. hepatica (length and pattern of uterine coils) but genetically they were more related to $F$. gigantica.

Key words: DNA sequences, PCR-RELP, Fasciola hepatogigantica n.sp.

\section{Introduction}

Fasciolosis, caused by the digenetic trematodes of the genus Fasciola, is one of the most important plant-borne helminth infections of human and livestock in many parts of the world
(Mas-Coma et al, 2005. 2009; Roknil et al, 2010). It is a major zoonosis that causes a great deal of economic loss throughout the tropical region of the world (Gorokhov and Sergiev, 2008) and is an emerging public health prob- 
lem in the Middle East (Alcaino and Apt, 1989; Hussein and Khalifa, 2010, Hussein et al, 2010).

Two species: F. hepatica and F. gigantica were recognized in humans and domestic farm animals. Since the second half of the last century, Price (1953) stated that mixed infections with the two species resulted in the emergence of flukes with intermediate morphological characters. At the extremes of their morphological range, some resemble $F$. hepatica, whereas others resemble $F$. gigantica, with intermediate forms occurring which may be involving the phenomena such as abnormal gametogenesis, diploidy, triploidy and mixoploidy, parthenogenesis, and hybridization events between different genotypes (Mas-Coma et al, 1997).

Understanding genetic structure and status of genetic variation of the parasite populations has important implications for epidemiology and effective control of fascioliasis (Ashrafi et al, 2006). On the other hand, intermediate forms between $F$. hepatica and $F$. gigantica have been morphologically recognized in most countries, (Ashrafi et al, 2006) and Arab Countries including Egypt (Allam et al, 2008; Hassan et al, 2008; Amor et al, 2011; El-Rahimy et al, 2012).

The identification of Fasciola species has been based solely on traditional morphological approaches. However, due to limitations of these methods, various molecular approaches have been developed and used for their identification and differentiation. These molecular methods have raised questions and spurred debate on the recognition of the intermediate Fasciola as a hybrid/intergrossed form between $F$. hepatica and $F$. gigantica (Agatsuma et al, 2000; Ashrafi et al, 2006; Ichikawa and Itagaki, 2010).

Molecular techniques such as PCR and its variants are used for the diagnosis of parasitic diseases and the identification of parasites, for the development of specific antigens for serological tests and for studying the immune response in the patients. They provided a more specific method than conventionally employed methods in epidemiological studies (Rognlie et al, 1994; Heckeroth and Tenter, 1999; Mostafa et al, 2003).

Hence, the aim of this study was to try to differentiate between the three fasciolid worms encountered in sheep and cattle in Sohag through a simple and rapid PCR-restriction fragment length polymorphism (RFLP) assay, using the common restriction enzymes AvaII based on a 618-bp-long sequence of the $28 \mathrm{~S}$ rRNA gene.

\section{Materials and Methods}

Adult fasciolid worms were isolated from liver of naturally infected sheep and cattle collected from various regions of Sohag Governorate. Fasciola hepatica and gigantica were identified based on morphological criteria of adults (Sahba et al, 1972; Muller, 2002). Together with some intermediate doughtful samples were washed extensively in $\mathrm{PBS}\left(37^{\circ} \mathrm{C}\right)$ and subsequently fixed in $70 \%$ ethanol and main- 
tained at $4^{\circ} \mathrm{C}$ until used for DNA extraction.

DNA Extraction by a new method (QIAamp DNA Mini Kit): 1- 5mg of tissue sample were cut into small pieces and placed in $1.5 \mathrm{ml}$ microcentrifuge tube then $180 \mu \mathrm{l}$ of buffer ALT was added and $20 \mu \mathrm{l}$ proteinase $\mathrm{K}$, mixed by vortexing and incubated at $56^{\circ} \mathrm{C}$ until the tissue was completely lysed. 2- After centrifugation $200 \mu 1$ Buffer ALT was added to the sample, mixed by pulse vortexing for 15 second and incubated at $70^{\circ} \mathrm{C}$ for $10 \mathrm{~min}$.

Carefully, the mixture was applied to the QIAamp Mini Kit column (in $2 \mathrm{ml}$ collection tube) without wetting the rim, centrifuged at $8000 \mathrm{rpm}$ for $1 \mathrm{~min}$. The mixture was carefully applied to the QIAamp Mini Kit column and 500 $\mu 1$ buffer AWI was added, centrifuged at $8000 \mathrm{rpm}$ for $1 \mathrm{~min}$.

The QIAamp Mini spin column was placed in a clean $2 \mathrm{ml}$ collection tube and the tube containing the filtrate was discarded and then $500 \mu 1$ buffer AW2 was carefully applied, centrifuged at full speed (14.000 rpm) for $3 \mathrm{~min}$.

Carefully, the QIAamp Mini spin column was opened and $100 \mu$ l buffer $\mathrm{AE}$ added, incubated at room temperature for $3 \mathrm{~min}$, then centrifuged at 8000 rpm for $1 \mathrm{~min}$, after which we incubated the last for $5 \mathrm{~min}$ with elution which increase the DNA yield.

Primer selection: After computerized study and comparison of nucleotide sequences in rDNA regions including $28 \mathrm{~S}$ rDNA of different Fasciola species, fragment of $618 \mathrm{bp}$ at the 5 ' end of the rDNA including 4 nucleotide dif- ferences between all Fasciola forms, were selected and a PCR method to amplify it was developed for the amplification of this 618-bp-long fragment of the 28S rDNA gene, the primers 28F1 (5' ACGTGATTACCCGCTGAACT3') and 28R600 (5' CTGAGAAAGTGCACTGACAAG 3') were used (Marcilla et al, 2002).

Each reaction mixture (total volume of $25 \mu \mathrm{l})$ contained $1 \mu \mathrm{l}$ of diluted (1:3 genomic DNA, $12.5 \mu 12 \mathrm{x}$ Promega master mix) and $0.2 \mu \mathrm{mol}$ of each primer. The reaction mixture was amplified in a TPersonal thermal cycle (Biometra, Germany).

The samples were subjected to an initial denaturation step at $94^{\circ} \mathrm{C}$ for 5 min, followed by 45 cycles of $30 \mathrm{~s}$ at $94^{\circ} \mathrm{C}, 30 \mathrm{~s}$ at $49^{\circ} \mathrm{C}$, and $60 \mathrm{~s}$ at $72^{\circ} \mathrm{C}$.

Finally, an extension step of $10 \mathrm{~min}$ at $72^{\circ} \mathrm{C}$ was used. Ten microlitres of PCR products were analyzed by electrophoresis on $1 \%(\mathrm{w} / \mathrm{v})$ agarose gels. A 100-bp DNA ladder marker was included on each gel for base-pair comparisons. Gels were visualized by staining with ethidium bromide as described by Sambrook et al. (1989).

Restriction fragment length polymorphism analysis: Advantage was taken of the previous knowledge about the exact nucleotide differences between the two liver fluke species for choosing the appropriate, specific and common restriction enzymes AvalI to carry out the necessary restriction fragment length poly-morphism analysis, which would allow us to distinguish between the three encountered forms.

Specific restriction enzymes were 
selected and lengths of resulting restriction fragments were predicted by means of the (BioDoc Analyzer Software). 12 microlitres of PCR products were completely digested with $15 \mu 1$ of AvaII (7.5 UI) restriction enzymes (Roche, Basel, Switzerland) at $37^{\circ} \mathrm{C}$. The digested DNA was analyzed by

Table 1: Restriction fragment length polymorphism (RFLP) patterns (in bp for each restriction band) of the 628-bp-long PCR fragments from liver fluke species generated after digestion with restriction enzymes.

\begin{tabular}{|c|c|}
\hline Fasciola species & Restriction enzyme Avall \\
\hline F. gigantica & 628,358 and 300 \\
\hline F. hepatogigantica & $628,541,358$ and 300 \\
\hline Fasciola hepatica & $628,575,165$ and 95 \\
\hline
\end{tabular}

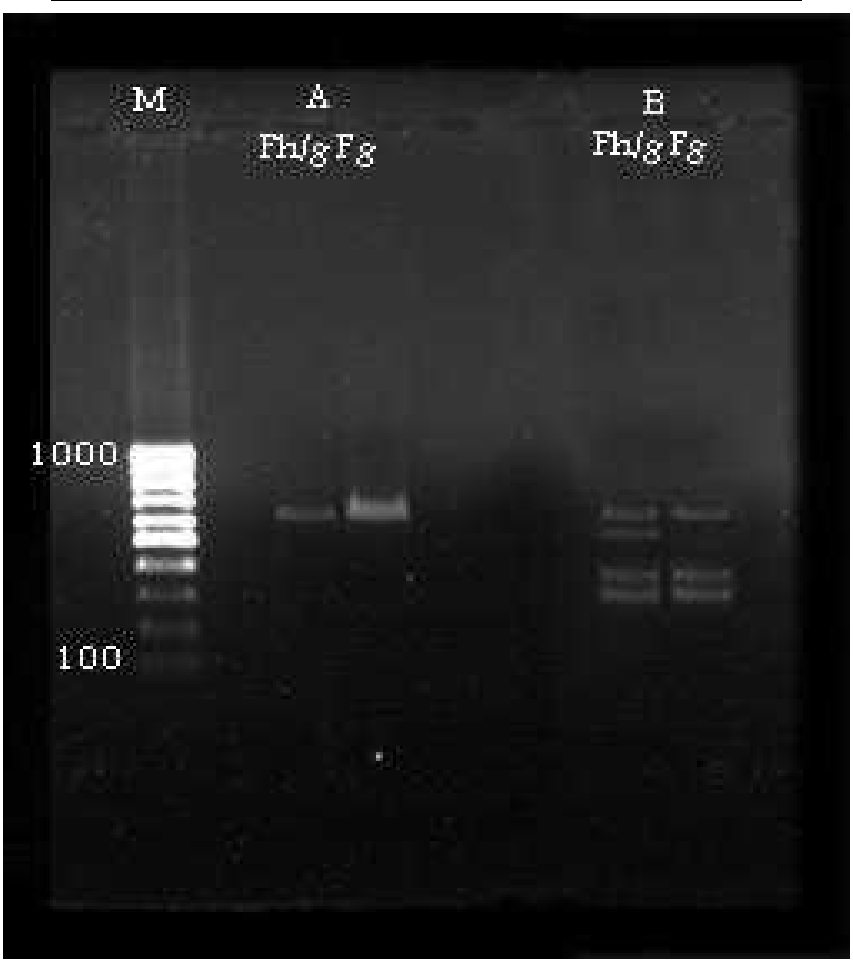

Figure 1: Restriction fragment length polymorphism (RFLP) patterns of PCR products of liver flukes after digestion with AvaII restriction enzymes.

Lane M: 100 bp DNA size marker:

Lanes A: Ethidium bromide staining pattern of the 648 bp-long PCR products from F.hepatogigantica (Fhig) and $F$. gigantica $(F g)$ DNA samples.

Lanes B: PCR products of the $F$. hepatogigantica (Fhig) and $F$. gigantica $(F g)$ after digestion with Avall restriction enzyme respectively. 


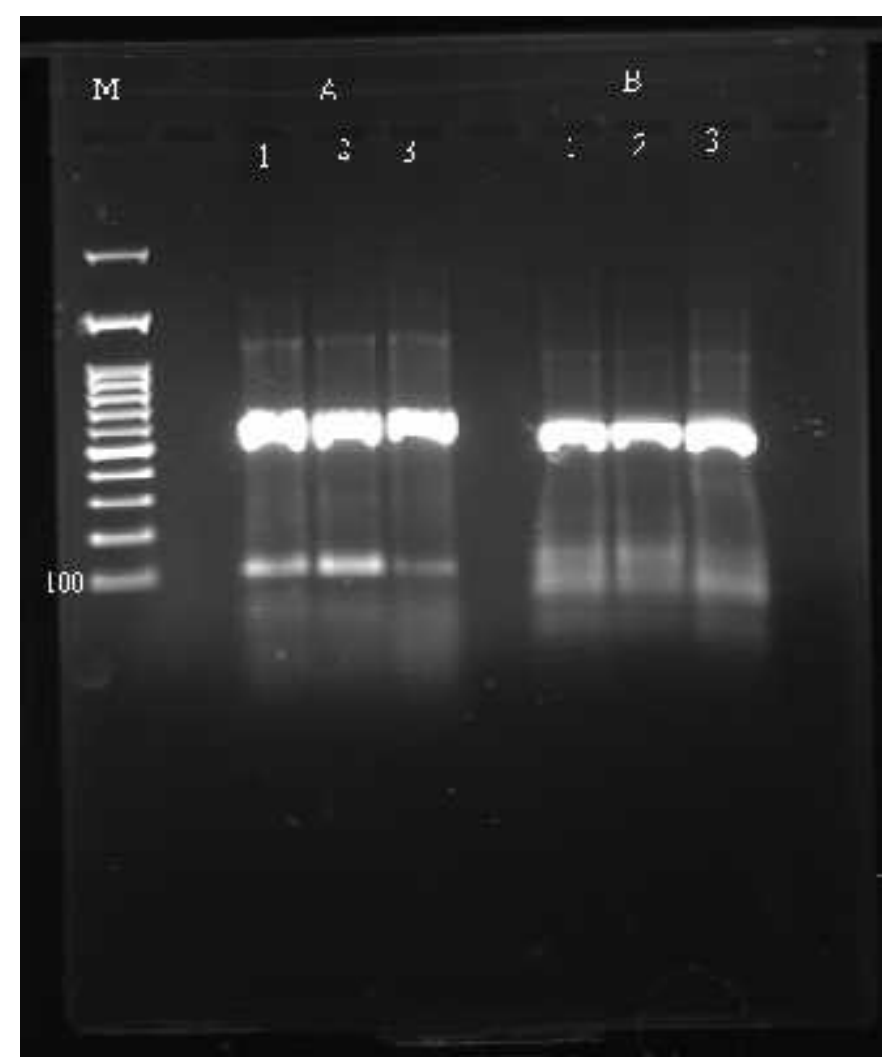

Figure 2: Restriction fragment length polymorphism (RFLP) patterns of PCR products of liver flukes after diges tion with AvaII restriction enzymes.

Lanes M: 100 bp DNA size marker:

Lanes A: Ethidium bromide staining pattern of the $648 \mathrm{bp}$-long PCR products from $F$. hepatica DNA samples.

Lanes B: PCR products of $F$. hepatica after digestion with Avall restriction enzyme.

\section{Discussion}

A number of fasciolid species have been described within the genus Fasciola, but only two species, Fasciola hepatica and Fasciola gigantica are commonly recognized as taxonomically valid species occurring in domestic animals and humans (Yamaguti, 1958; Mas-Coma et al, 1999; 2005). However, the two species can have considerable intra-specific differences in morphological features and other biologic characters, which can cause uncertainty in their accurate identification through the use of traditional approaches (Kendall, 1965; Itagaki, 1998). Moreover, recent experimental and field studies were in doubt that their definitive hosts may influence the morphometrics of adults and eggs (Valero et al, 2001).

It is very difficult to discriminate between $F$. hepatica and $F$. gigantica because of their many variations in their morphological characteristics although this is usually very important because of their different pathological effects. When the two species co-exist differentiation becomes very difficult, 
sometimes impossible, when dealing with few worms (Marcilla et al, 2002). The overlapping distributions of both species have become the basis of already longstanding controversy on the taxonomic identity of the Fasciola species occurring in Far and Middle East countries. At the extremes of their morphological range; some worms resemble $F$. hepatica whereas others resemble $F$. gigantica which lead to the assumption of the presence of different strains (Khalifa et al, 1979; Hussein and Khalifa, 2010), intermediate forms (Lotfy et al, 2002; Lin et al, 2007; Saki et al., 2011; Saira et al, 2011), hybr$\mathrm{id} /$ intergrossed forms (Le et al., 2008 and Thanh et al, 2008), size races (Srimuzipo et al, 2000) or genotypes (Ashrafi et al, 2006; Ali et al, 2010). Hence, it was a must to overcome this problem not only on morphometric basis but also by the study of the DNA pattern of the existing species.

According to the morphometric criteria proposed by Periago et al. (2006) for the differentiation of liver fluke adult fasciolids, the results of their study indicated the presence of $F$. hepatica, $F$. gigantica and intermediate forms in Egypt. Although the fasciolids can be characterized according to their morphometric techniques (Ashrafi et al, 2006), yet flukes with intermediate morphological characteristics can cause confusion (Terasaki et al, 1982; Itagaki et al, 2005a).

Although some species of Fasciola can be distinguished by iso- enzyme analysis, such approaches are time consuming and require specialist skills (Mc-Garry et al, 2007). Thus, there was unfortunately neither a direct coprological nor an indirect immunological test available for their identification. Specific differentiation can only be more accurately made by molecular tools (Periago et al, 2008). Over the last two decades, several PCR-based approaches, including PCR-linked restriction fragment length polymorphism (PCR-RFLP), PCR-linked single-strand co-information polymorphism (PCR-SSCP) and specific PCR assays have been developed for the accurate identification of Fasciola spp. (Marcilla et al, 2002, Huang et al, 2004; Lin et al, 2007, Roknil et al, 2010; Alasaad et al, 2011).

Previous studies in Japan (Itagaki et al,1998; Itagaki et al, 2005b) using the first and second internal transcribed spacers (ITS-1 and ITS-2) of ribosomal DNA (rDNA) demonstrated that the Japanese form of Fasciola represented both $F$. hepatica and $F$. gigantica, and the authors suggested that this form may be a hybrid between $F$. hepatica and $F$. gigantica. Furthermore, studies of Korean Fasciola specimens, using ITS-1, ITS-2 and the D2 region of the 28S rDNA as genetic markers, demonstrated that the Korean liver flukes were divided into $F$. hepatica, $F$. gigantica and intermediate forms (Agatsuma et al, 2000; Itagaki et al, 2005).

ITS1 and ITS2 sequences from rDNA provide reliable genetic markers for systematic molecular studies of parasites and interspecific variations (Huang et al, 2004) and these markers have been used to identify fasciolid species. Based on the sequences of the second internal-transcribed spacers 
(ITS-2) within the parasites' nuclear ribosomal DNA (rDNA) in China allowed the identification and differentiation of $F$. hepatica, $F$. gigantica and an intermediate form with no ampicons produced from heterogonous DNA samples (Ali et al, 2010)

The results of studies in Japan, Korea, China, Iran, Viet Nam and Egypt indicated that an 'intermediate' Fasciola, which may be a hybrid between $F$. hepatica and F.gigantica, is present in these countries (Itagaki et al, 1998; Agatsuma et al, 2000; Huang et al, 2004; Itagaki et al, 2005a, b; Ashrafi et al, 2006; Lin et al, 2007; Periago et al, 2008). Moreover, Karimi (2008) used $18 \mathrm{~S}$ rDNA-RFLP and sequencing, and reported the first molecular evidence of an intermediate genotype of Fasciola in Fars province, southern Iran.

Fascolid species in South America, Europe and Africa were distinguished based on RFLP patterns obtained with a 618-bp sequence of the 28S rRNA gene, using restriction enzymes AvaII and DraII. These sequences revealed a few nucleotide differences between the two species without intraspecific variations within species (Marcilla et al, 2002).

In the present study, a rapid and simple method was developed to differentiate Fasciola species by PCRRFLP assay. Adults of $F$. gigantica, $F$. hepatica and intermediate forms were isolated from livers of naturally infected animals (cow, sheep and buffalos) collected from various regions of Sohag Governorate. We used a new method to isolate DNA from the worm (QIAamp DNA Mini Kit) and Restric- tion fragment length polymorphism (RFLP) analysis of PCR products of liver flukes using Avall restriction enzymes. The result of regular PCR experiment for the amplification of the selected 28S rDNA fragment with the designed primer set yielded identical 618- bp-long PCR products for all types of Fasciola encountered. However, the RELP analysis indicated the presence of three different species. Using the same restriction enzymes, Mohammad et al. (2009) differentiated between $F$. hepatica and $F$. gigantica without mentioning the presence of intermediate forms.

\section{Conclusion}

The present results confirmed that three species of Fasciola are present in our locality: $F$. hepatica, $F$. gigantica and an intermediate forms which were named $F$. hepatogigantica $\mathrm{n}$. sp. on basis of having few morphometric characters from $F$. hepatica (length and pattern of uterine coils) but genetically, they were more related to $F$. gigantica.

\section{References}

Agatsuma, T, Arakawa, Y, Iwagami, M, et al, 2000: Molecular evidence of natural hybridization between Fasciola hepatica and $F$. gigantica. Parasitol. Int. 49:231-8.

Agatsuma, T, Blair, D, Vercruysse, J, et al, 2007: Molecular confirmation that Fasciola gigantica can undertake aberrant migrations in human hosts. J. Clin. Microbiol. 45:648-50.

Alasaad, S, Soriguer, R, Abu-Madi, M, et al, 2011: A fluorescence-based polymerase chain reaction-linked sin- 
gle strand conformation polymorphism (F-PCR-SSCP) assay for the identification of Fasciola spp. Parasitol. Res. 108:1513-17.

Alcaino, H, Apt, W, 1989: Algunos Antecedentes sobre la Fascioliasis Animal y Humana. Monog. Med. Vet. 11:14-29.

Ali, D, Zhang, W, Elsheikha, H, et al, 2010: Specific PCR-based assays for the identification of Fasciola species: their development, evaluation and potential usefulness in prevalence surveys. Am. J. Trop. Med. Hyg. 104, 1: 65-72.

Allam, A, El-Agamy, S, Helmy, M, 2008: Molecular and immunological characterization of Fasciola species. Br. J. Biomed. Sci. 59, 4:191-5

Amor, N, Farjallah, S, Salem, M, et al, 2011: Molecular characterization of Fasciola gigantica from Mauritania based on mitochondrial and nuclear ribosomal DNA sequences. Exp. Parasitol. 129, 2:127-36.

Ashrafi, K, Valero, M, Panova, M, et al, 2006: Phenotypic analysis of adults of Fasciola hepatica, Fasciola giganti$\mathrm{ca}$ and intermediate forms from the endemic region of Gilan, Iran. Parasitol. Int. 55:249-60.

El-Rahimy, HH, Mahgoub, AM, ElGebaly, NS, Mousa, WM, Antably, AS, 2012: Molecular, biochemical, and morphometric characterization of Fasciola species potentially causing zoonotic disease in Egypt. Parasitol. Res. 111, 3:1103-11.

Gorokhov, V, Sergiev, V, 2008: Incidence of human liver fluke infection.

Med. Parasitol. (Mosk), 2:57-9.
Hassan, AA, Abou-Zinadah, NYA, Shalaby, HA, Morsy, TA, 2008: Efficacy of some Fasciola gigantica antigens. J. Egypt. Soc. Parasitol. 38, 1: 243-54.

Heckeroth, A, Tenter, A, 1999: Development and validation of speciesspecific nested PCR for diagnosis of acute Sarcocystosis in sheep. Int. J. Parasitol. 29:1331-49.

Huang, W, He, B, Wang, CR, Zhu, XQ, 2004: Characterization of Fasciola species from mainland China by ITS-2 ribosomal DNA sequence. Vet. Parasitol. 120:75-83.

Hussein, A, Khalifa, R, 2010: Phenotypic description and prevalence of Fasciola species in Qena Governorate, Egypt with special reference to a new strain of Fasciola hepatica. J. King Saud Univ. (Science), 22:1-8.

Huusain, M, Ghafoor, B, Saboor, A, 2010: Factors affecting milk production in buffaloes: a case study. Pakistan J. Vet. 30:115-7.

Ichikawa M, Itagaki, T, 2010: Discrimination of the ITS1 types of Fasciola spp. based on a PCR-RFLP method. Parasitol. Res. 106:757-61.

Itagaki, T, Tsutsumi, K, Ito, K, Tsutsumi, Y, 1998: Taxonomic status of the Japanese triploid forms of Fasciola: comparison of mitochondrial ND1 and COI sequences with $F$. hepatica and $F$. gigantica. J. Parasitol. 84:445-8.

Itagaki, T, Kikawa, M, Sakaguchi, $\mathrm{K}$, et al, 2005a: Genetic characterization of parthenogenic Fasciola sp. in Japan on the basis of the sequences of ribosomal and mitochondrial DNA. Parasitol. 131:679-85. 
Itagaki, T, Kikawa, M, Terasaki, K, et al, 2005b: Molecular characterization of parthenogenic Fasciola sp. in Korea on the basis of DNA sequences of ribosomal ITS1 and mitochondrial NDI gene. J. Vet. Med. Sci. 67:1115-8.

Karimi, A, 2008: Genetic diagnosis of Fasciola species based on $18 \mathrm{~S}$ ribosomal DNA sequences, J. Biol. Sci. 8: 1166-73.

Kendal, SB, 1965: Relationships between the species of Fasciola and their molluscan hosts.Adv. Parasitol. 3:5995.

Khalifa, R, Sayed, F, Mounib, M, Bakeer, H, 1997: Studies on fascioliasis in Assuit Governorate, Upper Egypt. Morphological studies on adult worm. Egypt. J. Med. Sci. 18, 2:50715.

Le, T, De, N, Agatsuma, T, et al, 2008: Human fascioliasis and the presence of hybrid/introgressed forms of Fasciola in Vietnam. Int. J. Parasitol. 38:725-30.

Lin, R, Dong, S, Nie, K, et al, 2007: Sequence analysis of the first internal transcribed spacer of rDNA supports the existence of an intermediate Fasciola between $F$. hepatica and $F$. gigantica in mainland China. Parasitol. Res. 101:813-7.

Lotfy, W, El-Morshedy, H, Abou ElHoda, M, et al, 2002: Identification of the Egyptian species of Fasciola. Vet. Parasitol. 103:323-32.

Marcilla, A, Bargues, MD, MasComa, S, 2002: A PCR- RFLP assay for the distinction between Fasciola hepatica and Fasciola gigantica. Mol. Cell. Probes 16:327-33.
Mas-Coma, S, Bargues, MD, 1997: Human liver flukes: a review Research and Review in Parasitol. 57:145-218.

Mas-Coma, S, Bargues, MD, Valero, MA, 2005: Fascioliasis and other plant-borne trematode zoonoses. Int. J. Parasitol. 35:1255-78.

Mas-Coma, S, Esteban, JG, Bargues, MD, 1999: Epidemiology of human fascioliasis: a review and proposed new classification. Bull. WHO, 77: 340-6.

Mas-Coma, S, Valero, MA, Bargues, MD, 2009: Fasciola, lymnaeids and human fascioliasis, with a global overview on disease transmission, epidemiology, evolutionary genetics, molecular epidemiology and control. Adv. Parasitol. 69: 141-6.

McGarry, JW, Ortiz, PL, Hodgkinson, JE, Williams, D, 2007: PCRbased differentiation of Fasciola species (Trematoda: Fasciolidae) using primers based on RAPD-derived sequences. Ann. Trop. Med. Parasitol. 101:415-21.

Mohammad, BR, Hossein, M, Azadeh, M, et al, 2009: Identification and differentiation of $F$. hepatica and $F$. gigantica using a simple PCRrestriction enzyme method. Exp. Parasitol. 124, 2:209-13.

Mostafa, OM, Taha, HA, Ramadan, G., 2003: Diagnosis of Fasciola gigantica in snail using the polymerase chain reaction (PCR) assay. J. Egypt. Soc. Parasitol. 33, 3:733-42.

Muller, R, 2002: Worms and Human Disease, CABL International, Wallingford, Oxon, the United Kingdom. 
Periago, MV, Valero, MA, El Sayed, $M$, et al, 2008: First phenotypic description of $F$. hepatica/F. gigantica intermediate forms from the human endemic area of the Nile Delta, Egypt. Infect. Genet. Evolu. 8:51-8.

Periago, MV, Valero, MA, Panova, M, Mas-Coma, S, 2006: Phenotypic comparison of allopatric populations of $F$. hepatica and F. gigantica from European and African bovines using a computer image analysis system (CIAS). Parasitol. Res. 99:368-78.

Price, EW, 1953: The fluke situation in American ruminants. J. Parasitol. 39: 119-34.

Rognlie, M, Dimke, K, Knapp, S, 1994: Detection of Fasciola hepatica in infected intermediate hosts using RT-PCR. J. Parasitol. 80:748-55.

Roknil, MB, Mirhendi, H, Behnia, M, et al, 2010: Understanding genetic structure and status of genetic variation of the Fasciola hepatica isolates by RASPD-PCR and ribosomal ITS1 sequencing, Iranian J. IRCMJ. 12, 1:2732

Sahba, GH, Arfaa, F, Farahmandian, I, Jalali, H, 1972: Animal fascioliasis in Khuzestan, southwestern Iran. J. Parasitol. 58:712-6.

Saira, M, Maqbool, A, Yusuf, Z, et al, 2011: Phynotopic analysis of adult Fasciola spp. from Potohar region of Northern Punjab, Pakistan, Pakistan J. Zool. 43, 6:1069-77.

Saki, J, Khademvatan, S, Yousefi, E, 2011: Molecular-identification of animal Fasciola isolates in Southwest of Iran Aust. J. Bas. Sci., 5, 11:1878-83.
Sambrook, J, Fritsch, EF, Maniatis, T, 1989: Molecular Cloning. A Laboratory Manual, $2^{\text {nd }}$ edn. Cold Spring Harbor, New York: Laboratory Press.

Srimuzipo, P, Komalamisra, C, Choochote, W, et al, 2000: Comparative morphometry, morphology of egg and adult surface topography under light and scanning electron microscopies and metaphase karyotype among three size-races of Fasciola gigantica in Thailand Southeast Asian. J. Trop. Med. Publ. Hlth. 31:366-73.

Terasaki, K, Akahane, H, Hab, S, 1982: The geographical distribution of common liver flukes (the Genus Fasciola) with normal and abnormal spermato-genesis. Jpn. J. Vet. Sci. 44:22331 .

Thanh, HL, Nguyen, VD, Agatsuma, T, et al, 2008: Human fascioliasis and the presence of hybrid/introgressed forms of Fasciola hepatica and Fasciola gigantica in Vietnam. Int. J. Parasitol. 38, 6:725-30.

Valero, NA, Darce, M, Mas-Coma, S, 2001: Relationships between host species and morphometric patterns in $F$. hepatica adults and eggs from the Northern Bolvian Altiplano hyperendemic region. Vet. Parasitol. 102:85100.

Yamaguti, S, 1958: Systema Helminthum. Vol. I: The Digenetic Tremato des of Vertebrates. Inter-Science, New York.

Zhou, P, Chen, N, Zhang, RL, et al, 2008: Food-borne parasitic zoonoses in China perspective for control. Trends Parasitol. 24:190-6. 